Review 



\section{Survey of Italian neurological output in the three years 1989-1991}

Da Vico S., Massacesi L., Amaducci L.

Dipartimento di Scienze Neurologiche e Psichiatriche, Università degli Studi di Firenze

On the wave of the furore over the haphazard approach to academic promotion in Italy and the role of published work in it, our analysis clears the role of the neurological publications in the three years 1989-1991.

The data analysis, carried out by consulting on-line data bank and comparing the Italian production with that one of two sampled countries (France and Germany), shows that in the field of clinical neuroscience, this criticism is not in order.

Key Words: Neurology research — journal survey — on-line searches.

\section{Introduction}

Our analysis arose from the desire to conduct an unprejudiced survey of the status of Italy's neurological output in the three years 1989-1991. The idea was prompted by a paper published recently in Annals of Neurology, by P.E. Jamieson [1]. Jamieson's survey was concerned primarily with the composition of articles both by form (original articles, reviews and so on) and by content (areas of pathology, areas of clinical practice and so on) with a long time-span, which enabled the author to find, first of all, a very large percentage increase in neurological output in the decade 19801990.

On the wave of the furore over the haphazard approach to academic promotion in Italy and the role of published work in it $[2,3,4,5,6]$ we set out to clear the ground of ambiguity without indulging in Italocentricity. We therefore decided to begin our analysis by comparing the output of Italy with that of two European countries (France and Germany) engaged in this field of research and then to consider the Italian panorama from within. For our survey we consulted on-line data banks, now an indispensable tool for any in depth study, which has the prestigious merit of marking the start of a burgeoning of literature that had no precedent before these methods were introduced.

\section{Method}

The survey was based on Medline, the data bank of the National Library of Bethesda, a source of the highest standing in the field of biomedical literature. Although substantially valid, Medline does have limitations. It covers some 3600 publications in over 70 countries, a very creditable number but far from exhausting the world's medical offerings. Then there is a physiological slowness in the indexing of articles, which sometimes appear on the database several months after publication. This applies particularly to non American journals, which suffer not only from under-representation but also from delay in screening.

On the methodological front, the key words used for a research may not be those used by the Bethesda archivists in indexing articles, and this gives rise to inaccuracies and/or ambiguities. Similarly, a survey of scientific work by Italian neurological centers yields different data if con- 


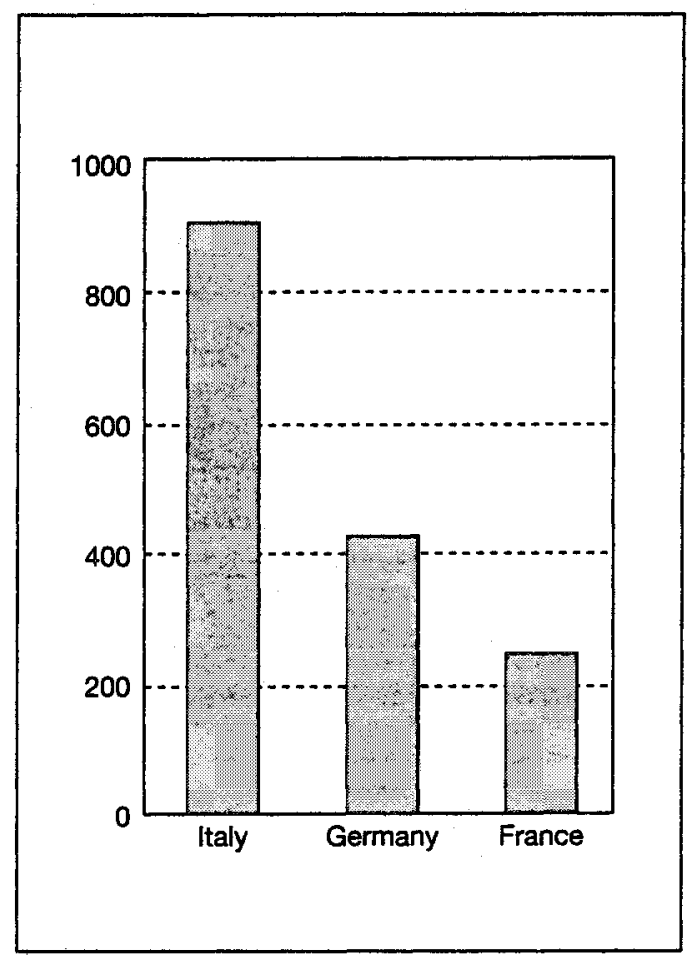

Fig. 1.

ducted on a countrywide rather than a city-by-city basis.

The first part of our survey was conducted in the following way: we questioned the database with the commands cs (corporate source) =Italy, $c s=$ Germany, $c s=$ France with the instruction cs = neurol? so as to include only neurological centers. The point of adding the question mark was to include every possible word-ending (English neurology, neurologic, French neurologie, neurologique and so on), for it must be remembered that on Medline only titles of articles are translated, not the names of the institutions from which they come.

To obtain more meaningful results from the enormous undifferentiated mass of publications present on Medline, we classified periodicals by level according to conventional criteria of priority, that is, taking into account the impact factor (index, published by Science Citation Index, directly proportional to the number of citations obtained by a journal in a given period) and the territoriality of journals, as when we confined the field of investigation to European periodicals.

Thus the first level consisted of journals of unquestioned international prestige (New England Journal of Medicine; Lancet; BMJ; Journal of Clinical Investigation), the second consisted of the most highly regarded American neurological journals (Neurology; Annals of Neurology; Archives of Neurology; Stroke; Journal of the Neurological Sciences), and lastly the third consisted of European journals (Acta Neurologica Scandinavica, Journal of Neurology, Neurosurgery and Psychiatry; Brain; Acta Neuropathologica (Berlin); Revue Neurologique (Paris); Acta Neurologica Belgica; European Neurology, Italian Journal of the Neurological Sciences; Journal of Neurology). Finally, to limit the time-span we confined our attention to the three years 1989-1991. With regard to attendance of the three samplecountries at the Meeting of the American Academy of Neurology in the years considered, the search was carried out manually, because the abstracts presented at the meetings and related proceedings form part of the so-called gray literature not indexed on Medline.

We conducted the second part of our study, on the national panorama, on the same strategic lines but confining the search to individual cities, centers of neurological research, questioning the database with $\mathrm{cs}=$ neurol? and $\mathrm{cs}=$ city name.

\section{Results}

The biomedical literature considered, entirely indexed on Medline, yielded the following results for 1989-1991: Italy 904 articles, Germany 428, France 245 (Fig. 1).

Considering the three categories of journals stated under Method, we find that Italy published 174 articles in European journals, Germany 132 and France 46 (Fig. 2) in the three years examined. In the category of American neurological journals Italy led with 81 publications against 61 for Germany and 38 for France. In the category of the high-prestige international medical journals we find Italy with 4 publications, France with 2 and Germany with 1.

The trend of attendance of the three sample countries at the American Academy of Neurology in 1989-1991 is shown in Fig. 3. In 1989 Italy presented officially 46 papers, in 199056 and in 1991 it was present with 56 abstracts to reach 71 in 1992. The corresponding figures for France were $32,27,28$ and 45 and for Germany 8, 17, 24 and 32. Table I shows the numbers of neurological papers published by Italian neurological research centers grouped by city and by the three levels of journals stated under Method.

\section{Discussion}

Despite the limitations of a survey that is not allinclusive, we feel that our analysis supplies a fair 


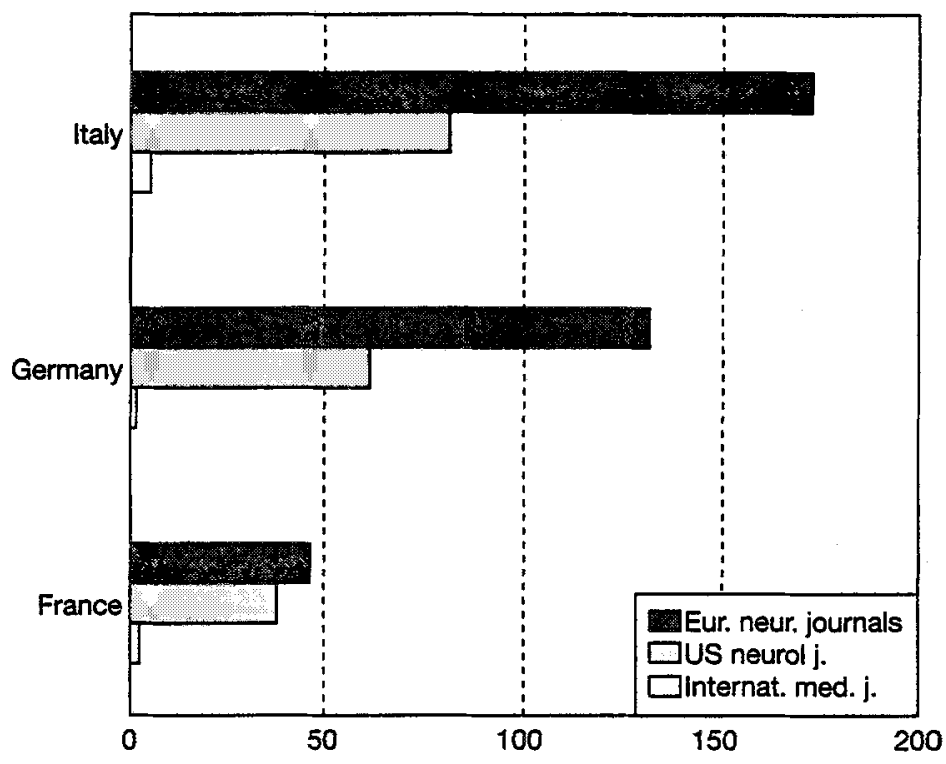

Fig. 2.

TABLE I. Numbers of papers on neurology published by Italian research centers in the years 1989 1991 grouped by center.

\begin{tabular}{|c|c|c|c|c|c|}
\hline City & $\begin{array}{c}\text { Medical } \\
\text { journals* }\end{array}$ & European $^{\star \wedge}$ & $\begin{array}{l}\text { rological jour } \\
\text { American }^{\star \star *}\end{array}$ & Total & Medline \\
\hline $\begin{array}{l}\text { Roma } \\
\text { Milano } \\
\text { Bologna } \\
\text { Pavia } \\
\text { Torino } \\
\text { Napoli } \\
\text { Firenze } \\
\text { Genova } \\
\text { Messina } \\
\text { Pisa } \\
\text { Padova } \\
\text { Modena } \\
\text { Siena } \\
\text { Parma } \\
\text { Chieti } \\
\text { Bari } \\
\text { Brescia } \\
\text { Gorizia } \\
\text { Sassari } \\
\text { Perugia } \\
\text { Catania } \\
\text { Cagliari } \\
\text { Verona } \\
\text { Ferrara }\end{array}$ & $\begin{array}{l}\overline{2} \\
- \\
- \\
\overline{1} \\
- \\
- \\
- \\
- \\
- \\
- \\
- \\
- \\
- \\
- \\
-\end{array}$ & $\begin{array}{r}49 \\
79 \\
22 \\
19 \\
16 \\
14 \\
18 \\
17 \\
13 \\
10 \\
5 \\
13 \\
10 \\
8 \\
10 \\
4 \\
9 \\
5 \\
4 \\
5 \\
2 \\
5 \\
4 \\
3\end{array}$ & $\begin{array}{r}16 \\
27 \\
8 \\
4 \\
5 \\
3 \\
4 \\
6 \\
1 \\
-5 \\
- \\
-2 \\
- \\
-1 \\
5 \\
- \\
- \\
-\end{array}$ & $\begin{array}{r}65 \\
104 \\
29 \\
23 \\
21 \\
17 \\
21 \\
23 \\
14 \\
10 \\
10 \\
13 \\
10 \\
10 \\
10 \\
4 \\
10 \\
5 \\
9 \\
6 \\
2 \\
5 \\
4 \\
3\end{array}$ & $\begin{array}{r}291 \\
287 \\
88 \\
82 \\
77 \\
65 \\
65 \\
60 \\
44 \\
43 \\
33 \\
32 \\
28 \\
26 \\
26 \\
18 \\
17 \\
17 \\
16 \\
15 \\
14 \\
12 \\
11 \\
11\end{array}$ \\
\hline
\end{tabular}

- N. Engl. J. Med., Lancet, BMJ, J. Clin. Invest.

- Acta Neurol. Scand., J. Neurol. Neurosurg. Psychiat., Brain, Acta Neuropathol. (Berlin), Rev. Neurol. (Paris), Acta Neurol. Belg., Eur. Neurol., Ital. J. Neuro. Sci., J. Neurol.

Neurology, Anṇ. Neurol., Arch. Neurol., Stroke, J. Neurol. Sci. 


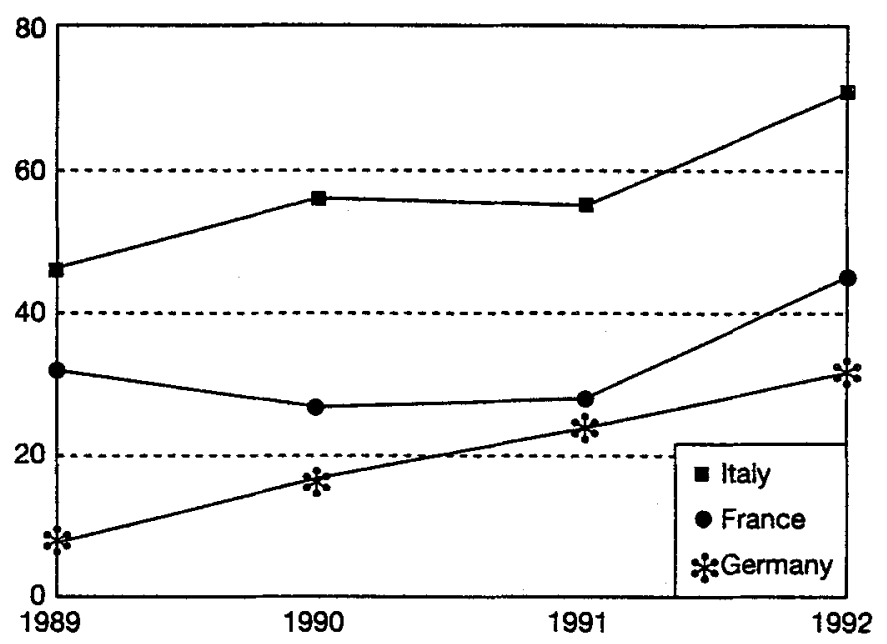

Fig. 3.

enough picture of the Italian contribution to neurological literature.

Medline is a mine of information and an analysis based on it is more comprehensive than one based on a few authoritative journals (as in the case of Jamieson). Our method of breaking down the data by level seemed to be the best way of reading the data critically. Thus the large volume of Italian published work indexed on Medline is confirmed even when the items of greatest prestige are considered separately from the total. Admittedly,
Italy has a definite tendency to publish a great deal, not all of it based on originality. However, at odds with recent comment playing down the weight of Italian biomedical literature, the upshot of our findings seems to be that in the field of the clinical neurosciences this criticism is not in order.

Special thanks to Ms Ilaria Stortoni and Ms Elena Nesti for their unfailing cooperation.

\section{Sommario}

Il nostro studio nasce sull'onda delle polemiche sorte intorno alle facili promozioni accademiche in Italia e sul relativo ruolo giocato dalle pubblicazioni scientifiche, cercando di fare il punto sulla produzione neurologica nel triennio 1989-1991.

L'analisi dei dati, compiuta attraverso l'utilizzo delle banche dati on-line e comparando la produzione italiana con due paesi-campione, Francia e Germania, dimostra come, almeno per quanto riguarda l'ambito neurologico, tale polemica non possa aver luogo.

\section{References}

[1] JAMIESON P.E.: Neurology Research: a journal survey, 1980-1990. Ann. Neurol. 32:87-93, 1992.

[2] GAETANI G.F., FERRARIS A.M.: Academic promotion in Italy. Nature 353:10, 1991

[3] FABBRI L.M.: Rank injustices and academic promotion. Lancet ii:860, 1987.
[4] Amati P., Cammarano B., Fantoni A., Macino G.: Troubles at Rome University. Nature 345:658, 1990.

[5] Cantani A.: Problems of Rome University. Nature 346:788, 1990.

[6] Autti F., Baroni C., CaO A., Fantoni A.: Academic promotion in Italy. Lancet 338:1337, 1991.

Address reprint requests to: Prof. L. Amaducci, Dipart. di Scienze Neurologiche e Psichiatriche, Università degli studi di Firenze - v.le Morgagni, 85 - 50134 Firenze 